\title{
FLORA MALESIANA PRECURSOR FOR THE TREATMENT OF MORACEAE 7: FICUS SUBGENUS UROSTIGMA
}

\author{
C.C. BERG \\ The Norwegian Arboretum/Department of Biology, University of Bergen, \\ N-5259 Hjellestad, Norway; Nationaal Herbarium Nederland, Universiteit Leiden branch, \\ P.O. Box 9514, 2300 RA Leiden, The Netherlands.
}

\begin{abstract}
SUMMARY
The sections and subsections of Ficus subg. Urostigma are described and their Malesian species listed and keyed out. Two new species are established in the subgenus: F. kochummeniana and F. miqueliana. The combinations F. chrysolepis Miq. subsp. novoguineensis (Corner) C.C. Berg and F. crassiramea (Miq.) Miq. subsp. stupenda (Miq.) C.C. Berg are made. Ficus subpisocarpa Gagnep., F. lawesii King, and F. rigo F.M. Bailey are reinstated.
\end{abstract}

Key words: Moraceae, Ficus subg. Urostigma, Malesia.

\section{INTRODUCTION}

Subgenus Urostigma is with c. 280 species the largest main subdivision of the genus (Berg, 2003). It is pantropical and morphologically distinct by the ability to produce aerial adventitious roots and the presence of a single waxy gland at the base of the midrib of the lamina beneath. The majority of the species are potentially hemi-epiphytic or hemi-epilithic.

The subgenus comprises two subdivisions quite different from the majority. Sect. Galoglychia (Gasp.) Endl. is characterised by the structure of the ostiole which is slitshaped as the two upper ostiolar bracts are descending and by the basal bracts (Berg \& Wiebes, 1992). This section, with 72 species, is confined to Africa, Madagascar and adjacent Indian Ocean Islands, and the Arabian Peninsula. The other subdivision is sect. Stilpnophyllum, described below. The American subdivision, sect. Americana Miq. with c. 100 species, differs from the Old World section Urostigma mainly in the presence of only two basal bracts (Miquel, 1847; Corner, 1958).

\section{SUBDIVISIONS AND SPECIES IN MALESIA}

Two sections, each with 2 subsections, occur in Malesia.

Ficus subg. Urostigma (Gasp.) Miq. (1867) 285 sect. Urostigma (Gasp.) Endl. (1848) 34

Figs with 3, mostly persistent basal bracts; ostiole circular, the upper ostiolar bracts not descending. Staminate flowers scattered among the pistillate ones or concentrated near the ostiole; anthers with 2 thecae. Stigmas papillate and cohering. 
Distribution - From West Africa to the Pacific, with c. 90 species

Subdivision - The section can be divided into 2 subsections, with the same names as used for sections of the subgenus by Corner (1960): Urostigma and Conosycea, the former including sect. Leucogyne Corner (1960).

Ficus subg. Urostigma sect. Urostigma subsect. Urostigma (Gasp.) C.C. Berg, subsect. nov.

Based on: Urostigma Gasp., Giorn. Bot. Ital. 2 (1844) 214.

Trees, with \pm clear morphological indications of intermittent growth, often deciduous. Leaves spirally arranged, often articulate or subarticulate; lamina often ovate to subovate; cystoliths mostly only beneath; venation reticulate to subscalariform or partly parallel to the lateral veins; petiole relatively long. Figs axillary, more commonly just below the leaves, and/or ramiflorous on up to c. $1 \mathrm{~cm}$ long spurs (short-shoots); basal bracts small, persistent or caducous; internal hairs present and often \pm chaffy or absent. Staminate flowers near the ostiole (or scattered among the pistillate ones). Tepals red(dish). Ovary red-brown (or white).

Distribution - From West Africa and Madagascar through the Asian mainland to Japan and through (southern) Malesia to Australia and the Pacific; mostly in relatively dry types of vegetation and/or seasonal conditions, often monsoon forest, savannah, or littoral vegetation, often on or near rocks, at low altitudes. The subsection comprises c. 25 species, of which 5 are African-Madagascan (Berg \& Wiebes, 1992), 4 are Indian, F. prolixa G. Forst. is confined to the Pacific region, F. henneana Miq. to Australia, and one or two species to the Sino-Himalayan region.

Morphology - The morphological indications of intermittent growth are different colours of parts of twigs of current or recent growth and of previous season's growth, the transition is marked by a section with very short internodes, which in some species bore (bear) stipules forming terminal buds. As these features are also found in the two species included in sect. Leucogyne, F. amplissima $\mathrm{Sm}$. from India and F. rumphii, are included in the subsection, in spite of the deviating colour of the fruit.

Note - Ficus arnottiana (Miq.) Miq. (1867) from India and Sri Lanka is transferred from subsect. Conosycea in which it was included by Corner (1960: 379) to subsect. Urostigma, as defined here. However, var. subcostata Corner (1960: 379) proves to belong to subsect. Conosycea, being either a form of $F$. glaberrima or a distinct species.

Malesian species recognised in subsect. Urostigma: 1) F. caulocarpa (Miq.) Miq. (incl. F. weinlandii K. Schum. in K. Schum. \& Lauterb., 1905, see below); 2) F. concinna (Miq.) Miq.; 3) F. prasinicarpa Elmer; 4) F. religiosa L.; 5) F. rumphii Blume; 6) F. saxophila Blume; 7) F. subpisocarpa Gagnep. (reinstated = F. superba var. japonica); 8) F. superba (Miq.) Miq. (excl. var. henneana and var. japonica, see above); 9) F. virens Aiton. - For other synonyms and (included) varieties see Corner's checklist (1965: 6-11). 
Ficus subg. Urostigma sect. Urostigma subsect. Conosycea (Miq.) C.C. Berg, subsect. nov.

Based on: Urostigma Gasp. subg. Conosycea Miq., Fl. Ind. Bat. 1, 2 (1859) 349. - Ficus subg. Urostigma sect. Conosycea (Miq.) Corner, Gard. Bull. Singapore 17 (1960) 371.

Trees, without clear indication of intermittent growth. Leafy twigs \pm angular, scars of the petioles often prominent on leafless twigs. Leaves spirally arranged (or subdistichous), (sub)coriaceous, mostly broadest in the middle or above the middle, the margin entire and sometimes callose (towards the base), venation scalariform to reticulate or partly to entirely parallel to the lateral veins; petiole relatively thick and short, often drying blackish; stipules often with a thickened median part. Figs in pairs (or solitary) in the leaf axils (or just below the leaves), more frequently sessile than pedunculate, (solitary) enclosed by calyptrate bud covers or not; receptacle large to small, often longer than wide; basal bracts large to small, often unequal (in size, shape, or presence of a thickened median part or a keel), mostly persistent; ostiole closed (the upper ostiolar bracts overlapping) or \pm open (the upper ostiolar bracts not or partly imbricate), the 3 upper ostiolar bracts often unequal in size, sometimes only 2 clearly visible and the third just; internal hairs mostly absent (present in few species). Staminate flowers disperse. Tepals mostly (partly) red or reddish. Ovary mostly partly reddish, sometimes entirely reddish.

Distribution - This section comprises c. 63 species and ranges from the Pacific and Australia to Madagascar; 53 species occur in Malesia.

Delimitation - This subsection coincides with sect. Conosycea as defined by Corner, 1960. Two Madagascan species are included (Berg \& Wiebes, 1992).

Subdivision - Three main groups of species can be recognised:

1) Ficus sundaica-group (ser. Callophylleae, Dubiae, Glaberrimae, Perforatae, Subvallidae, and subser. Crassirameae Corner (1960) 373-374), comprising the species numbered: 10, 11, 15, 17, 18, 21, 25, 26, 28, 29, 32, 34, 36, 37, 38, 41, 42, 43, 44, 45, $46,47,48,50,51,54(?), 55,56,59,60,61,62$, and 63 . In this group the indumentum is mostly whitish, sometimes yellowish; it is inconspicuous and the leaves are glabrous. The figs are mostly sessile with well-developed basal bracts. The position of $F$. glaberrima and $F$. lawesii is somewhat uncertain.

2) Ficus drupacea-group (subser. Drupaceae, Indicae, and Zygostricheae Corner (1960) 372), comprising the species numbered: 12, 19, 20, 22, 23, 24, 27, 30, 31, 33(?), $35,39,52$, and 53 . This group is characterised by indumentum that is often conspicuously present and brown. The tertiary venation varies from (sub)scalariform to reticulate and is often \pm prominent. The figs are pedunculate or sessile; the basal bracts are often small or caducous.

3) Ficus benjamina-group (ser. Benjamineae Corner (1960) 374), comprising the species numbered: $13,14,16,40,49,57$, and 58 . This group is characterised by tertiary venation distinctly parallel to the lateral veins and often nearly as strong. Indumentum is absent or sparse.

Note - The type of F. longistipulata Kochummen (1998: 208) is not found in SAN and has not yet been traced elsewhere, and thus not been examined; hence, its identity is still uncertain. 
Malesian species recognised in subsect. Conosycea: 10) F. acamptophylla (Miq.) Miq. (incl. F. palungensis Weiblen (Laman \& Weiblen, 1998: 279)); 11) F. altissima Blume; 12) F. annulata Blume; 13) F. archboldiana Summerh.; 14) F. balete Merr.; 15) F. benghalensis L.; 16) F. benjamina L.; 17) F. binnendijkii (Miq.) Miq. (incl. F. ngii Kochummen, 1998; excl. var. coriacea Corner, 1960 and var. pallescens Weiblen, 1998); 18) F. borneensis Kochummen (incl. F. chewii Kochummen, 1998 and F. kerangasensis Kochummen, 1998); 19) F. bracteata (Miq.) Miq.; 20) F. calcicola Corner; 21) F. callophylla Blume; 22) F. chrysolepis Miq., a) subsp. chrysolepis, b) subsp. novoguineensis (Corner) C.C. Berg (=F. novoguinensis, see below); 23) F. consociata Blume; 24) F. cordatula Merr.; 25) F. corneri Kochummen, 1998 (incl.F. lowii King var. borneensis Corner, 1960); 26) F. crassiramea (Miq.) Miq., a) subsp. crassiramea (incl. F. ashtonii Kochummen, 1998, F. subgelderi var. rigida (Miq.) Corner, 1960, and F. subtecta Corner, 1960), b) subsp. stupenda (Miq.) C.C. Berg (=F. stupenda); 27) F. cucurbitina King; 28) F. curtipes Corner; 29) F. delosyce Corner; 30) F. depressa Blume; 31) F. drupacea Thunb.; 32) F. dubia King; 33) F.forstenii Miq.; 34) F. glaberrima Blume (excl. var. bracteata Corner and synonyms as $F$. lawesii, see below, and var. siamensis Corner); 35) F. globosa Blume; 36) F. involucrata Blume; 37) F. juglandiformis King; 38) F. kerkhovenii Valeton; 39) F. kochummeniana C.C. Berg (=F. retusa var. borneensis Corner, see below); 40) F. kurzii King; 41) F. lawesii King (reinstated = F. glaberrima var. bracteata p.p., see above); 42) F. lowii King; 43) F. maclellandii King; 44) F. microcarpa L.f. (excl. var. hilii (Miq.) Corner, var. saffordii (Merr.) Corner, and var. rigo (F.M. Bailey) Corner, reinstated, see below); 45) F. microsyce Ridl.; 46) F. miqueliana C.C. Berg (see below); 47) F. pallescens (Weiblen) C.C. Berg (= incl. F. binnendijkii Miq. var. coriacea Corner and var. pallescens Weiblen, 1998); 48) F. paracamptophylla Corner; 49) F. patellata Corner (incl. F. benjaminoides Corner); 50) F. pellucidopunctata Griff.; 51) F. pisocarpa Blume (incl. F. episima Corner and Urostigma tjiela Miq., see below); 52) F. pubilimba Merr.; 53) F. retusa L. (excl. var. borneensis Corner, see above); 54) F. rigo F.M. Bailey (reinstated, see above); 55) F. soepadmoi Kochummen, 1998; 56) F. spathulifolia Corner; 57) F. stricta (Miq.) Miq.; 58) F. subcordata Blume (incl. F. polygramma Corner); 59) F. subgelderi Corner (excl. var. rigida (Miq.) Corner, see above); 60) F. sumatrana (Miq.) Miq. (incl. F. dulitensis Kochummen, 1998 and F. palaquiifolia Corner); 61) F. sundaica Blume; 62) F. tristaniifolia Corner; 63) F. xylophylla (Miq.) Miq. - For other synonyms and (included) varieties see Corner's check-list (1965: 12-24).

\section{Ficus subg. Urostigma sect. Stilpnophyllum Endl. (1848) 35}

Trees, mostly hemi-epiphytic, often large. Leaves spirally arranged, sometimes subdistichous; lamina symmetric, margin entire; tertiary venation largely parallel to the lateral veins and often slightly weaker than the primary lateral veins; stipules often relatively long. Figs axillary; basal bracts 2 or 3, early caducous (and \pm cucullate) or (sub)persistent; ostiole slit-shaped or tri-radiate and the upper ostiolar 2 or 3 bracts descending, thickened at the base, or the ostiole circular and the 3 upper ostiolar bracts horizontal and not thickened; wall \pm clearly differentiated into a hard outer layer (not becoming fleshy at maturity) and an inner layer which can be thick and in which the fruits are partly to entirely embedded; internal hairs absent. Staminate flowers disperse; stamens 1 (or 2); thecae fused over the top of the filament, dehiscent with a single crescentic (or 
circular) slit or thecae free and each dehiscent with a longitudinal slit. Tepals reddish. Stigmas often bifid, not distinctly papillate and not cohering. Fruits often (partly or entirely) embedded in the inner layer of the wall of the fig or the swollen pedicels.

Distribution - Section Stilpnophyllum comprises 20 species, of which some recently treated by Dixon (2001a, b) and Dixon et al. (2001). It is the only subdivision of the genus distinctly centred in Australia. The disjunct occurrence of F. elastica in the western Malesian region and the Asian mainland is noteworthy.

Subdivision - The section comprises two subsections: Stilpnophyllum and Malvanthera.

Ficus subg. Urostigma sect. Stilpnophyllum subsect. Stilpnophyllum (Endl.) C.C.

Berg, subsect. nov.

Based on: Ficus sect. Stilpnophyllum Endl., Gen. Pl. Suppl. 4, 2 (1848) 35.

Stipules connate. Upper ostiolar bracts well-developed horizontal and imbricate, closing the entrance, in the ostiole the upper bracts horizontal and interlocking, only the lower ones descending. Anthers with 2 distinct thecae, each dehiscing longitudinally.

Distribution - Monotypic; F. elastica in the Asian mainland and western Malesia; widely cultivated.

Malesian species recognised in subsect. Stilpnophyllum: 65) F. elastica Roxb. ex. Hornem.

Ficus subg. Urostigma sect. Stilpnophyllum subsect. Malvanthera (Corner) C.C.

Berg, subsect. nov.

Based on: Ficus subg. Urostigma sect. Malvanthera Corner, Gard. Bull. Singapore 17 (1960) 374.

Stipules free. Upper ostiolar bracts 2 or 3, descending, aperture tri-radiate or slit-shaped. Anthers reniform (or peltate) at the apex of the filament and dehiscing with a single, crescentic or equatorial slit, occasionally two theca dehiscing longitudinally.

Distribution - Eighteen species, of which 14 in Australia; 2 of them extend to adjacent parts of Malesia and/or the Pacific. One species is confined to Malesia and one to the Solomon Islands (Berg, 2002), and two occur both in Malesia and Melanesia.

Malesian species recognised in subsect. Malvanthera: 66) F. brachypoda (Miq.) Miq.; 67) F. glandifera Summerh.; 68) F. hesperidiiformis King (incl. F. augusta Corner, F. heteromeka Corner, F. mafuluensis Summerh., F. sterrocarpa Diels, and F.xylosycia Diels); 69) F. obliqua G. Forst.; 70) F. rhizophoriphylla King. - For other synonyms and (included) varieties see Corner's check-list (1965: 12-24), and for F. brachypoda and F. obliqua Dixon (2001b) and Dixon et al. (2001), respectively.

\section{NEW SPECIES, NAMES, AND COMBINATIONS}

Ficus chrysolepis Miq. subsp. novoguineensis (Corner) C.C. Berg, comb. \& stat. nov.

Based on: Ficus novoguineensis Corner, Gard. Bull. Singapore 18 (1961) 84. - Type: Henty NGF 11658 (holo LAE), Papua New Guinea, Lae Botanical Gardens, 4 Jan. 1960. 
Ficus crassiramea (Miq.) Miq. subsp. stupenda (Miq.) C.C. Berg, comb. \& stat. nov.

Based on: Ficus stupenda Miq., Ann. Mus. Bot. Lugd.-Bat. 3 (1867) 286. - Urostigma giganteum Miq., Fl. Ind. Bat. 1, 2 (1859) 351. - Type: Zollinger 1676 (holo L), Java, base of Mt Salak.

Ficus kochummeniana C.C. Berg, stat. \& nom. nov.

Based on: Ficus retusa L. var. borneensis Corner, Gard. Bull. Singapore 17 (1960) 393. - Type: Hallier 1074 (holo L), Indonesia, Kalimantan, S. Sambas.

Tree up to $30 \mathrm{~m}$ tall, hemi-epiphytic or (secondarily?) terrestrial. Branches drying brown to greyish. Leafy twigs 3-5(-7) mm thick, \pm angular, minutely white puberulous and with dark brown hairs; periderm persistent. Leaves spirally arranged; lamina subobovate to obovate (to oblanceolate to oblong or to elliptic), $4-15(-18)$ by $1.5-6(-7.5)$ $\mathrm{cm}$, coriaceous, apex acuminate to rounded, base cuneate to obtuse, margin \pm revolute towards the base or flat; upper surface minutely white puberulous on the midrib or only with dark brown appressed hairs or glabrous (glabrescent?), lower surface minutely white puberulous on the midrib and lateral veins and with sparse to dense dark brown appressed hairs, mainly on and along the veins; midrib (at least the lower part) impressed above, lateral veins $6-8$ pairs, often \pm impressed above, the basal pair distinct, up to $1 / 3-1 / 2(-2 / 3)$ the length of the lamina, unbranched, tertiary venation reticulate, prominent; waxy gland at the base of the midrib; petiole (0.5-)1-2.5 cm long, 1-2 $\mathrm{mm}$ thick, minutely white puberulous, drying brown; stipules $1-2.5 \mathrm{~cm}$ long, minutely white puberulous and with dark brown hairs, subpersistent or caducous. Figs axillary, paired (or solitary), often crowded, sessile; basal bracts 3, 3-5 mm long, (sub)equal, with dark brown hairs, glabrescent, persistent; receptacle subglobose, $0.5-0.8 \mathrm{~cm}$ diam. when dry, minutely white puberulous or mostly only with dark brown appressed hairs (glabrescent?), orange to red at maturity, apex slightly convex to flat, ostiole 2.5-3 mm diam., flat to slightly prominent, surrounded by a rim, the 3 upper ostiolar bracts fully imbricate; wall (almost) smooth when dry; internal hairs absent. Tepals red(dish). Ovary reddish to whitish.

Distribution - Thailand; Malesia: Sumatra (western), Malay Peninsula, Borneo.

Habitat - Forest, at low altitudes.

Note - This species differs from F. retusa, in which it was included as var. borneensis, e.g., in the longer petioles, the conspicuously prominent tertiary venation beneath, the \pm impressed lateral veins, the often acuminate apex of the lamina, and the often subpersistent stipules.

Ficus miqueliana C.C. Berg, spec.nov. - Fig. 1

Fico subgelderi similis, laminis glabris, fici receptaculo minore subgloboso, ostiolo inaperto differt. - Typus: Jacobs 4834 (holo BO; iso K, L, and according to the label also in A and CGE), Indonesia, Java, Besuki, Mt Raung, 18 May 1957.

Tree up to c. $30 \mathrm{~m}$ tall, hemi-epiphytic or (secondarily?) terrestrial. Branches drying greyish to brown. Leafy twigs 2-4 mm thick, \pm angular, glabrous (or sparsely and minutely whitish puberulous on the scars of the stipules); periderm persistent. Leaves spirally arranged; lamina oblong to elliptic (to (sub)obovate), (3-)8-16 by (2-)3.5-7.5 


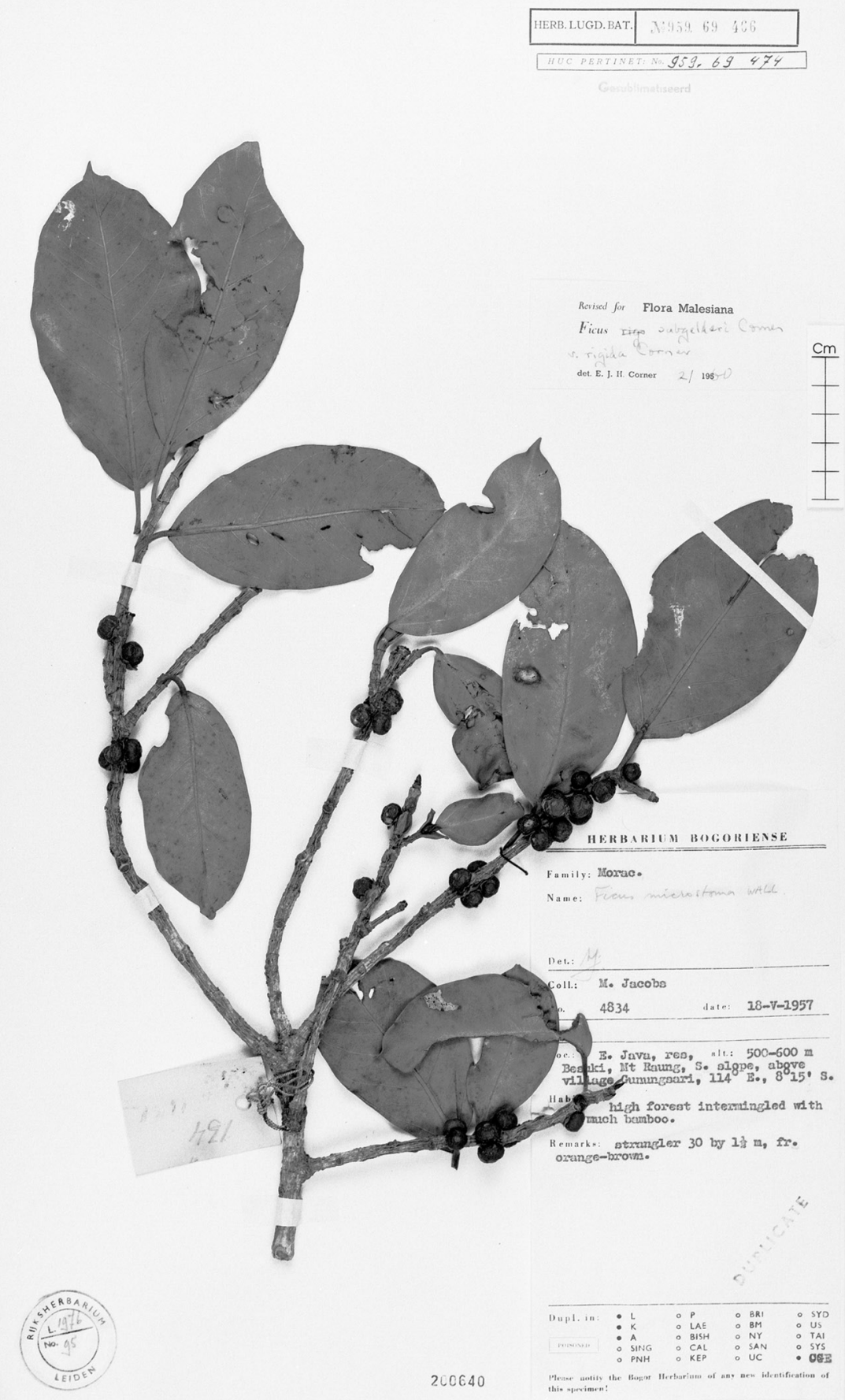

Fig. 1. Ficus miqueliana C.C. Berg. Leafy twigs with figs (Jacobs 4834, L), Indonesia, Java, Besuki, Mt Raung, 18 May 1957. 
$\mathrm{cm}$, coriaceous, apex short-acuminate, the acumen obtuse, base obtuse to rounded and auriculate to cordulate (to subcordate); both surfaces glabrous; cystoliths on both sides; midrib almost flat but slightly impressed towards the base above, lateral veins 5-8 pairs, the basal pair distinct, up to $1 / 4-1 / 3(-1 / 2)$ the length of the lamina, (sparsely and faintly) branched or unbranched, departing from the midrib well above the base of the lamina, 1-3 pairs of smaller basal lateral veins below the main pair, tertiary venation reticulate; waxy gland at the base of the midrib; petiole 1-2 cm long, c. $2 \mathrm{~mm}$ thick, glabrous, drying blackish or brown; stipules (0.5-)1-1.5 cm long, glabrous (or partly sparsely and minutely white appressed-puberulous), caducous, often with a distinct median part. Figs axillary or just below the leaves, paired (or solitary), sessile; basal bracts 3,6-7 mm long, \pm unequal, 1 (or 2) with a distinct median part, glabrous (or sparsely whitish puberulous), persistent; receptacle depressed-globose, $0.8-1 \mathrm{~cm}$ diam. when dry, (sub)glabrous, orange-brown at maturity, apex slightly convex, ostiole c. 3 mm diam., flat to slightly prominent, closed, the 3 upper ostiolar bracts fully imbricate, 2 visible and the third just; wall \pm shrivelled to almost smooth when dry; internal hairs absent. Tepals reddish. Ovary partly red.

Distribution - Java (eastern).

Habitat - Forest, at low altitudes.

Notes - 1. Material included in this species was treated as $F$. subgelderi var. rigida by Corner (1960: 387). Ficus miqueliana differs from F. subgelderi (as currently defined) by the absence of hairs on the surfaces of the lamina, on the petiole, and mostly also on the leafy twig and the basal bracts of the fig. The fig receptacle is smaller and different in shape and the ostiole is closed instead of open. The basal lateral veins depart from the midrib well above the base of the lamina, a feature also found in F. crassiramea and F. sundaica.

2. The species is known from five collections, all made in a small area in eastern Java.

Ficus pallescens (Weiblen) C.C. Berg, stat. nov.

Based on: Ficus binnendijkii (Miq.) Miq. var. pallescens Weiblen, Trop. Biodiversity 5 (1998) 266. - Typus: T. Laman 1195 (holo A n.v.; iso L), Borneo, Kalimantan, Gunung Palung National Park, 10 Oct. 1997.

\section{KEY TO THE SUBSECTIONS IN MALESIA}

1a. Ostiole tri-radiate or slit-shaped, the upper ostiolar bracts descending $\ldots \ldots \ldots$ $\ldots \ldots \ldots \ldots \ldots \ldots \ldots \ldots \ldots \ldots \ldots \ldots \ldots \ldots \ldots \ldots \ldots$ Subsect. Malvanthera

b. Ostiole circular, the upper ostiolar bracts horizontal $\ldots \ldots \ldots \ldots \ldots \ldots 2$

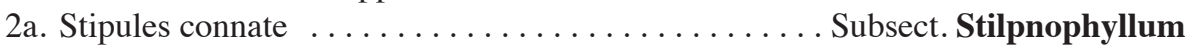

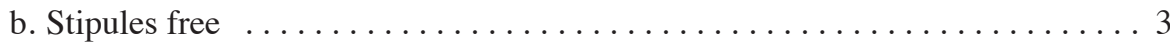

3a. Internodes conspicuously different in length, the proximal ones of a season's growth long, subsequently shorter, the ultimate ones very short, sometimes with persistent stipules forming terminal buds . . . . . . . . . . . . Subsect. Urostigma

b. Internodes not conspicuously different in length . . . . . . Subsect. Conosycea 


\section{KEY TO THE SPECIES OF SUBSECTION UROSTIGMA}

1a. Apex of the lamina caudate. - Cultivated, widespread ..... 4. F. religiosa

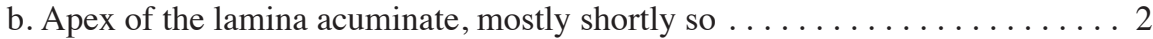

2a. Major basal lateral veins up to 1/3-1/2 the length of the lamina; cystoliths on both sides of the lamina (in dried material visible as minute pustules); ovary white. - Widespread

5. F. rumphii

b. Major basal lateral veins $1 / 10-1 / 3$ the length of the lamina; cystoliths (usually) only beneath; ovaries red(-brown)

3a. Lateral veins 4-7 pairs; margin of upper ostiolar bracts ciliolate. - Widespread

6. F. saxophila

b. Lateral veins 7-16 pairs; upper ostiolar bracts glabrous (or sparsely puberulous

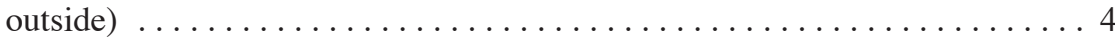

4a. Stipules (at the apices of leafy twigs) $0.8-1.5 \mathrm{~cm}$ long $\ldots \ldots \ldots \ldots \ldots 5$

b. Stipules (at the apices of leafy twigs) $0.2-0.8 \mathrm{~cm}$ long $\ldots \ldots \ldots \ldots \ldots 7$

5a. Epidermis of the petiole (usually) flaking off, at least at the uppermost and/or basal part; peduncle $0.1-0.5 \mathrm{~cm}$ long. - Widespread ...... 1. F. caulocarpa

b. Epidermis of the petiole persistent; peduncle $0.7-1.5 \mathrm{~cm}$ long or at most $0.1 \mathrm{~cm}$

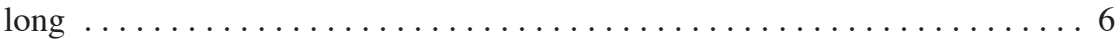

6a. Peduncle $0.7-1.5 \mathrm{~cm}$ long; basal bracts caducous. - Widespread 8. F. superba

b. Peduncle 0-0.1 cm long; basal bracts persistent. - Widespread . . 9. F. virens

7a. Epidermis of petiole usually flaking off, at least at the top of the petiole and/or the base; waxy gland in dry material in a groove in the base of the midrib; terminal stipules (usually) forming an ovoid (to subglobose) bud; basal bracts caducous, or if persistent, then usually splitting $\ldots \ldots \ldots \ldots \ldots \ldots \ldots$

b. Epidermis persistent; waxy gland not in a groove at the base of the midrib; basal bracts caducous or remaining entire $\ldots \ldots \ldots \ldots \ldots \ldots \ldots \ldots \ldots \ldots \ldots \ldots$

8a. Basal bracts persistent and splitting; fig receptacle $0.3-0.5(-0.7) \mathrm{cm}$ diam. when

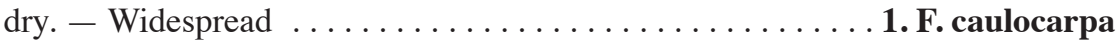

b. Basal bracts caducous; fig receptacle 0.7-1.2 cm diam. when dry. - Moluccas .

7. F. subpisocarpa

9a. Basal lateral veins up to $1 / 5-1 / 3$ the length of the lamina, mostly departing from the midrib at different distances from the base, their bases running parallel to the midrib. - Philippines, Sulawesi, Moluccas . . . . . . 3. F. prasinicarpa

b. Basal lateral veins up to $1 / 10-1 / 5$ the length of the lamina, their bases not running

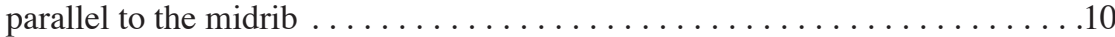

10a. Peduncle $0-0.1 \mathrm{~cm}$ long; basal bracts persistent. - Widespread . . 9. F. virens

b. Peduncle 0.1-0.3(-0.5) cm long; basal bracts caducous. - Malay Peninsula, Borneo, Philippines

2. F. concinna

\section{KEY TO THE SPECIES OF SUBSECTION CONOSYCEA}

1a. Figs pedunculate or sessile with a peduncle-like stipe $\ldots \ldots \ldots \ldots \ldots 2$

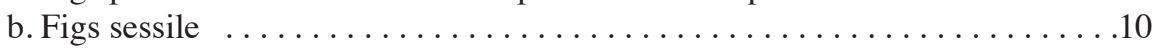

2a. Figs sessile with a peduncle-like stipe (the basal bracts at the base of the stipe) 3

b. Figs pedunculate (the basal bracts at the apex of the peduncle) .........4 
3a. Tertiary venation subscalariform; various parts often hairy. - New Guinea .... 31. F. drupacea

b. Tertiary venation largely parallel to the lateral veins; all parts glabrous. - Sumatra, Malay Peninsula, Borneo 32. F. dubia

4a. Apex of the peduncle widened into a rim (bearing the basal bracts inside) . . 5

b. Apex of the peduncle not widened into a rim . . . . . . . . . . . . 7

5a. Midrib of the lamina beneath laterally hairy, often with hairs concentrated in the axils of the lateral veins. - Widespread .

30. F. depressa

b. Midrib of the lamina beneath with hairs evenly distributed or absent . . . . 6

6a. Fig receptacle subglobose, the basal bracts c. 3 mm long. - Philippines, Sulawesi,

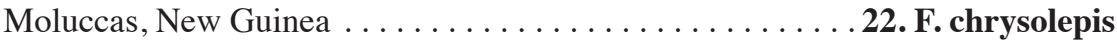

b. Fig receptacle usually ellipsoid to ovoid, rarely subglobose, the basal bracts 3-11

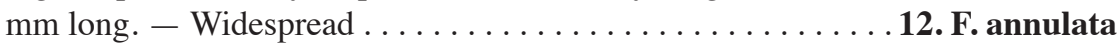

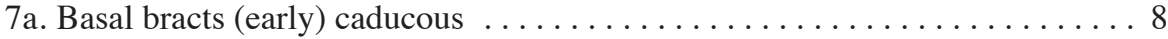

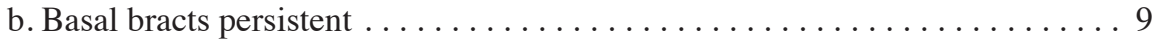

8a. Basal lateral veins up to $1 / 10-1 / 6$ the length of the lamina; stipules $1-1.5(-1.7)$ cm long. - Sumatra, Malay Peninsula, Java, Borneo, Lesser Sunda Islands . . .

34. F. glaberrima

b. Basal lateral veins up to $1 / 4-1 / 3(-1 / 2)$ the length of the lamina; stipules $0.5-1$

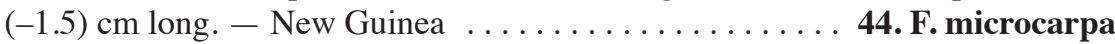

9a. Fig receptacle $0.4-0.7(-1) \mathrm{cm}$ diam. when dry, the peduncle $0.7-1.2 \mathrm{~cm}$ long, 2 upper ostiolar bracts visible, these imbricate; leafy twigs glabrous or sparsely and minutely white puberulous. - Borneo, Philippines, Moluccas, New Guinea

41. F. lawesii

b. Fig receptacle $0.8-1.2 \mathrm{~cm}$ diam. when dry, the peduncle $0.2-0.7 \mathrm{~cm}$ long, 3 upper ostiolar bracts visible, these unequal in size and hardly or not imbricate; leafy twigs with dark brown appressed hairs. - Sumatra, Malay Peninsula, Java, Borneo . .

35. F. globosa

10a. Lateral and smaller veins (and often also the apex of the midrib) invisible. Malay Peninsula, Borneo.

62. F. tristaniifolia

b. Lateral veins visible, smaller veins varying from clearly visible to \pm obscure 11

11a. Tertiary venation parallel to the lateral veins (such as in F. elastica); lateral veins

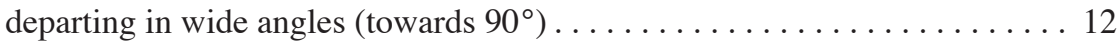

b. Tertiary venation partly to largely parallel to the lateral veins to reticulate towards the margin or reticulate to subscalariform towards the margin; lateral veins usually departing in more acute angles $\left(\right.$ about $\left.60^{\circ}\right) \ldots \ldots \ldots \ldots \ldots \ldots \ldots \ldots$

12a. Fig receptacle ellipsoid, ovoid, or cylindrical; petioles and stipules usually $1.5-3$

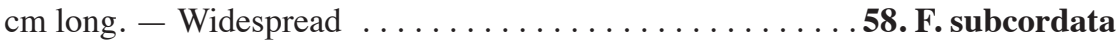

b. Fig receptacle subglobose, or if distinctly longer than wide, then the petioles and/or

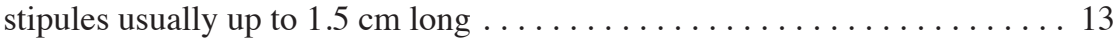

13a. Fig receptacle usually $1-1.8 \mathrm{~cm}$ diam. when dry; basal bracts $3-8(-10) \mathrm{mm}$

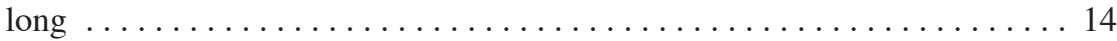

b. Fig receptacle $0.5-1 \mathrm{~cm}$ diam. when dry, or if more than $1 \mathrm{~cm}$ diam., then the

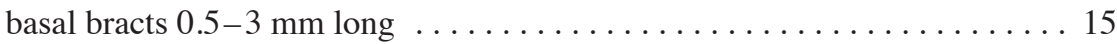

14a. Basal bracts subequal in size and shape; ostiole closed. - New Guinea . . . . . . 
b. Basal bracts unequal in size and shape; ostiole \pm open. - Sumatra, Malay Penin-

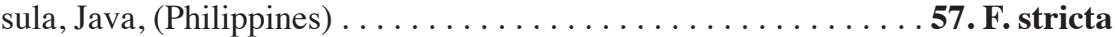

15a. Stipules $1.5-2.5 \mathrm{~cm}$ long; ostiole closed; basal bracts mostly \pm connate. - Su-

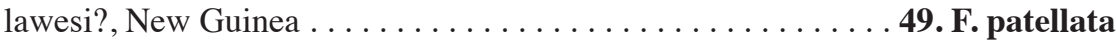

b. Stipules usually $0.5-1.5 \mathrm{~cm}$ long; ostiole \pm open; basal bracts free . . . . . 16

16a. Midrib (at least in the lower part) of the lamina slightly prominent; petiole, stipules and fig receptacle when dry usually blackish. - Sumatra, Malay Peninsula,

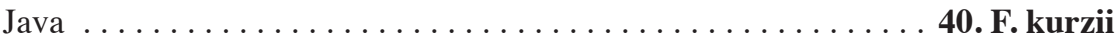

b. Midrib (at least in the lower part) of the lamina slightly impressed; petiole, stipules and fig receptacle when dry usually pale yellowish. - Widespread ........

16. F. benjamina

17a. Lamina mostly up to $10 \mathrm{~cm}$, rarely up to $15 \mathrm{~cm}$ long . . . . . . . . . 18

b. Lamina mostly longer than $10 \mathrm{~cm}$, up to c. 20 or up to c. $30 \mathrm{~cm} \ldots \ldots \ldots .42$

18a. Fig receptacle longer than wide (ellipsoid, obovoid, ovoid, or cylindrical) . 19

b. Fig receptacle about as long as wide (subglobose) . . . . . . . . . . 24

19a. Ostiole closed, the 3 upper ostiolar bracts clearly imbricate . . . . . . . . 20

b. Ostiole \pm open, the 3 upper ostiolar bracts not or partly imbricate . . . . . . 21

20a. Fig receptacle $1.5-2 \mathrm{~cm}$ diam. when dry; basal bracts 5-10 $\mathrm{mm}$ long. - Wide-

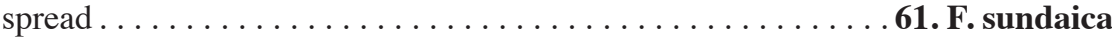

b. Fig receptacle $0.5-1(-1.2) \mathrm{cm}$ diam. when dry; basal bracts $3-5 \mathrm{~mm}$ long. -

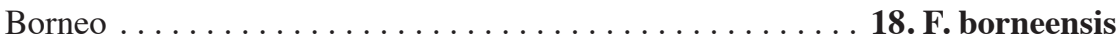

21a. Basal lateral veins up to $1 / 10-1 / 4$ the length of the lamina . . . . . . . 22

b. Basal lateral veins up to $1 / 4-1 / 3(-1 / 2)$ the length of the lamina . . . . . . 23

22a. Petiole $0.5-1(-1.5) \mathrm{cm}$ long; base of the lamina rounded to obtuse, apex rounded to obtuse to short-acuminate. - Sumatra, Borneo . . . . . 10. F. acamptophylla

b. Petiole 1.5-2.5(-3) cm long; base of the lamina cuneate to obtuse, apex acuminate. - Sumatra, Malay Peninsula, Borneo, Philippines .. 50. F. pellucidopunctata

23a. Stipules distinctly hairy; margin of the lamina not callose towards the base; apex of the lamina acuminate. - Sumatra, Malay Peninsula, Borneo

59. F. subgelderi

b. Stipules glabrous (or sparsely and minutely puberulous); margin of the lamina usually callose towards the base; apex of the lamina rounded to short-acuminate. - Widespread ..................... 21. F. callophylla

24a. Indumentum on leafy twigs and stipules brown. - Malay Peninsula . . . . . . .

20. F. calcicola

b. Indumentum absent or, if present, then white $\ldots \ldots \ldots \ldots \ldots \ldots \ldots$

25a. Lower surface of the lamina \pm densely puberulous on the veins. - Malay Peninsula

52. F. pubilimba

b. Lower surface of the lamina glabrous, or if hairy, then minutely so and only on

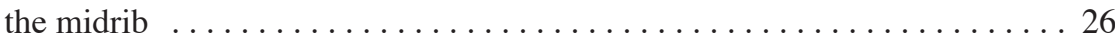

26a. Ostiole \pm open, the 3 upper ostiolar bracts not or partly imbricate . . . . . 27

b. Ostiole closed, the 3 upper ostiolar bracts clearly imbricate . . . . . . . . 36

27a. Basal lateral veins branched, 1/3-1/2 the length of the lamina; margin of the lamina not callose towards the base. - Sumatra, Malay Peninsula, Java, Borneo, Philippines 
b. Basal lateral veins unbranched, mostly up to $1 / 4$ the length of the lamina, or if up to $1 / 3(-1 / 2)$, then the margin of the lamina \pm callose towards the base . . . 28

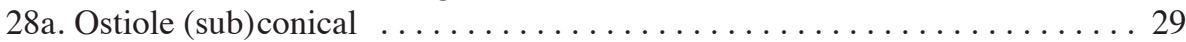

b. Ostiole flat, slightly prominent, or slightly sunken . . . . . . . . . 30

29a. Fig receptacle $0.4-0.7 \mathrm{~cm}$ diam. when dry; stipules $0.5-1(-1.2) \mathrm{cm}$ long. -

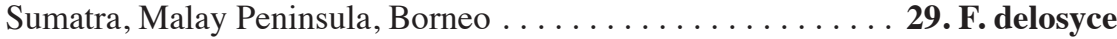

b. Fig receptacle $(0.5-) 0.7-1.2 \mathrm{~cm}$ diam. when dry; stipules $(0.5-) 1-1.5(-2) \mathrm{cm}$

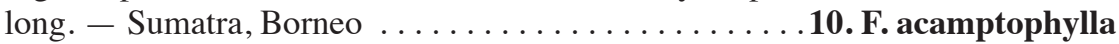

30a. Tertiary and smaller veins of the lamina obscure beneath; stipules $0.5-1 \mathrm{~cm}$ long; fig receptacle $0.3-0.4 \mathrm{~cm}$ diam. when dry. - Sumatra, Malay Peninsula . . . . .

45. F. microsyce

b. Tertiary and smaller veins of the lamina distinct; stipules mostly $1-2 \mathrm{~cm}$ long, or if $0.5-1 \mathrm{~cm}$ long, then the fig receptacle $0.5-0.8(-1) \mathrm{cm}$ diam. when dry . . 31

31a. Basal bracts $3-8(-10) \mathrm{mm}$ long; fig receptacle $0.7-1.3(-1.8) \mathrm{cm}$ diam. when

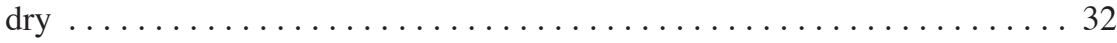

b. Basal bracts $1-3 \mathrm{~mm}$ long; fig receptacle $0.3-0.6(-0.8) \mathrm{cm}$ diam. when dry, basal lateral veins up to $1 / 4-1 / 2$ the length of the lamina, and/or petioles, stipules, and

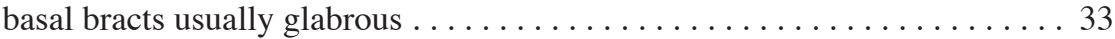

32a. Basal lateral veins up to 1/10-1/4 the length of the lamina; petioles, stipules, and basal bracts minutely white puberulous; margin of the lamina not callose towards

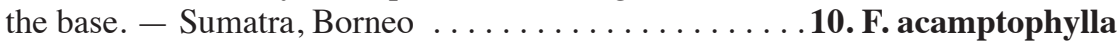

b. Basal lateral veins up to $1 / 4-1 / 3(-1 / 2)$ the length of the lamina; petioles, stipules, and basal bracts usually glabrous; margin of the lamina \pm callose towards the base. - Widespread .................... 21. F. callophylla

33a. Petioles and stipules usually $0.5-1 \mathrm{~cm}$ long; basal lateral veins usually $1 / 4-1 / 2$ the length of the lamina . . . . . . . . . . . . . . . . 34

b. Petioles and stipules usually $1-2 \mathrm{~cm}$ long; basal lateral veins usually $1 / 10-1 / 4$, sometimes in $F$. rigo up to $1 / 3$, the length of the lamina . . . . . . . . . 35

34a. Basal bracts 2-3 mm long; apex of the lamina short-acuminate (with an obtuse acumen) to obtuse to subacute to rounded. - Widespread . 44. F. microcarpa

b. Basal bracts 1.5-2 mm long; apex of the lamina usually acuminate to subcaudate. - Sumatra, Malay Peninsula, Borneo .............. 47. F. pallescens

35a. Basal bracts 1-2 mm long; apex of the lamina acuminate. - Sumatra, Malay

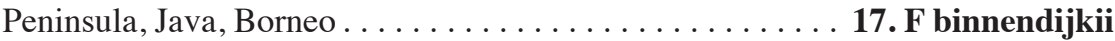

b. Basal bracts 2-3 mm long; apex of the lamina rounded to obtuse. - New Guinea ................ rigo

36a. Indumentum of leafy twigs, petioles, and stipules (usually) brownish; basal bracts

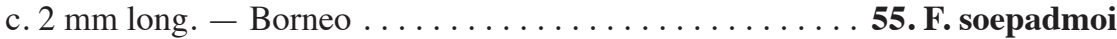

b. Indumentum of leafy twigs, petioles, and stipules absent or whitish, or if brownish, then the basal bracts $3-5(-10) \mathrm{mm}$ long $\ldots \ldots \ldots \ldots \ldots \ldots \ldots \ldots \ldots$

$37 \mathrm{a}$. Stipules and/or petioles usually $0.5-1 \mathrm{~cm}$ long; apex of the lamina rounded to obtuse or to subacute to short-acuminate, the acumen obtuse; basal bracts $0.5-4$

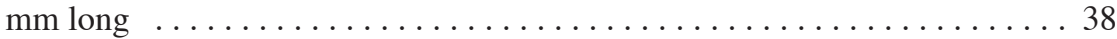

b. Stipules and petioles usually $1-1.5 \mathrm{~cm}$ long, or up to 3 or $4 \mathrm{~cm}$ long, respectively; apex of the lamina acuminate, or if rounded to obtuse and basal bracts $2-3 \mathrm{~mm}$ long, then only occurring in New Guinea or the basal bracts $4-8(-10) \mathrm{mm}$ long 
38a. Tertiary venation (nearly) invisible. - Malay Peninsula, Borneo

56. F. spathulifolia

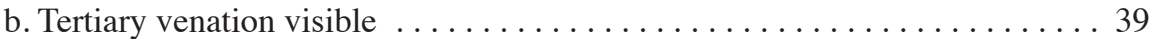

39a. Fig receptacle with internal hairs; midrib of the lamina flat to slightly prominent or impressed above; acumen of the lamina obtuse. - Widespread

44. F. microcarpa

b. Fig receptacle without internal hairs; midrib of the lamina impressed above; acumen of the lamina usually acute. - Sumatra, Malay Peninsula, Java, Borneo, Philippines, Sulawesi?

60. F. sumatrana

40a. Basal bracts $2-3 \mathrm{~mm}$ long. - New Guinea ............ 54. F. rigo

b. Basal bracts $3-8(-10) \mathrm{mm}$ long $\ldots \ldots \ldots \ldots \ldots \ldots \ldots \ldots \ldots \ldots, 41$

41a. Apex of the lamina acuminate, the acumen usually acute; margin of the lamina not callose. - Sumatra, Malay Peninsula, Java, Borneo, Philippines, Sulawesi?

60. F. sumatrana

b. Apex of the lamina rounded to short-acuminate, the acumen usually obtuse; margin of the lamina \pm callose towards the base. - Widespread . . . 21. F. callophylla

42a. Fig receptacle longer than wide $\ldots \ldots \ldots \ldots \ldots \ldots \ldots \ldots \ldots \ldots \ldots$

b. Fig receptacle about as long as wide (or wider than high) $\ldots \ldots \ldots \ldots 66$

43a. Fig receptacle $2-3.5 \mathrm{~cm}$ diam. when dry ................. 44

b. Fig receptacle $0.3-2 \mathrm{~cm}$ diam. when dry ................. 49

44a. Apex of lamina rounded; basal lateral veins mostly up to $1 / 3-1 / 2$ the length of the lamina. - Sumatra, Malay Peninsula, Borneo ....... 63. F. xylophylla

b. Apex of lamina acuminate (to obtuse); basal lateral veins mostly $1 / 8-1 / 3$ the length of the lamina ........................... 45

45a. Stipules 1-1.5(-2) cm long; (main) basal lateral veins often branched, often 1-3 pairs of smaller lateral veins below the main ones; base of the lamina cordate to rounded; basal lateral veins $0.5-4 \mathrm{~mm}$ long ................ 46

b. Stipules (1.5-)2-4 cm long; basal lateral veins unbranched, usually without smaller lateral veins below the (main) ones; base of the lamina rounded to cuneate, or cordate, then the basal bracts $10-20(-30) \mathrm{mm}$ long . .......... 47

46a. Stipules brownish (woolly) tomentose to subvillous or glabrous; fig receptacle glabrous inside. - Widespread . .............. 31. F. drupacea

b. Stipules sparsely to densely yellowish sericeous; fig receptacle hairy inside, on the inner surface or also on the pedicels. - Philippines, Sulawesi .........

24. F. cordatula

47a. Lateral veins (8-)12-20 pairs; basal lateral veins up to $1 / 20-1 / 10$ the length of the lamina. - Widespread .................... 12. F. annulata

b. Lateral veins $8-12$ pairs; basal lateral veins up to $1 / 8-1 / 3(-1 / 2)$ the length of the

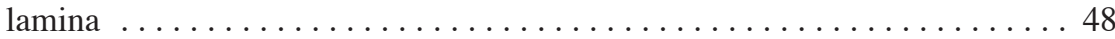

48a. Basal bracts $8-10 \mathrm{~mm}$ long, ovate to elliptic, the apex obtuse; tertiary venation partly parallel to the lateral veins. - Sumatra ...... 37. F. juglandiformis

b. Basal bracts 10-20(-30) $\mathrm{mm}$ long, semicircular to suborbicular, the apex rounded. - Java, Borneo ................. 26b. F. crassiramea subsp. stupenda

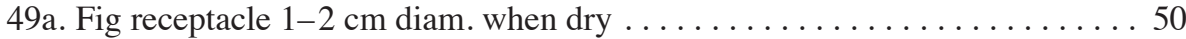

b. Fig receptacle $0.3-1 \mathrm{~cm}$ diam. when dry $\ldots \ldots \ldots \ldots \ldots \ldots \ldots \ldots \ldots$ 
50a. Indumentum (partly) set(ul)ose with irritating hairs . . . . 27. F. cucurbitina

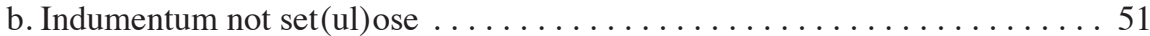

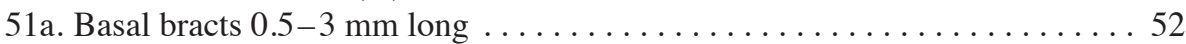

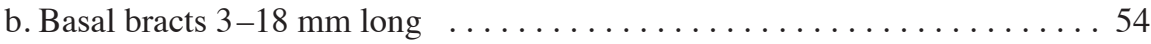

52a. Stipules 1-1.5(-2) cm long; base of the lamina cordate to rounded. - Wide-

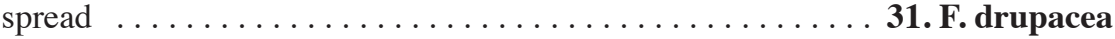

b. Stipules 2-4 cm long; base of the lamina rounded or to subattenuate . . . . 53

53a. Basal lateral veins curved, usually running close to the margin, unbranched; ostiole closed, the 3 upper ostiolar bracts clearly imbricate. - Malay Peninsula ......

42. F. lowii

b. Basal lateral veins straight or slightly curved, branched; ostiole \pm open, the 3 upper ostiolar bracts not or slightly imbricate. - Widespread . . . . 11. F. altissima

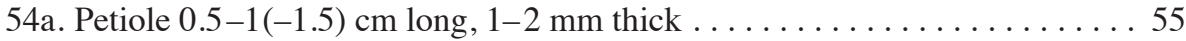

b. Petiole $1.5-5.5 \mathrm{~cm}$ long, $2-3(-5) \mathrm{mm}$ thick $\ldots \ldots \ldots \ldots \ldots \ldots \ldots$

55a. Basal bracts 3-5 mm long; fig receptacle 0.5-1.2 cm diam. when dry. - Sumatra,

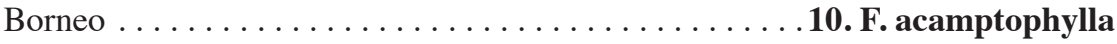

b. Basal bracts 5-8 $\mathrm{mm}$ long; fig receptacle $1.5-2 \mathrm{~cm}$ diam. when dry

61. F. sundaica

56a. Ostiole \pm open, the 3 upper ostiolar bracts not or slightly imbricate; lateral veins 5 or 6 (or 7) pairs; stipules yellowish to whitish sericeous to puberulous. Sumatra, Malay Peninsula . . . . . . . . . . . . . 59. F. subgelderi

b. Ostiole closed, the 3 upper ostiolar bracts clearly imbricate; lateral veins 7-12 pairs, or if less, then the stipules glabrous or minutely white puberulous . . 557

57a. Basal bracts $10-18 \mathrm{~mm}$ long, covering $1 / 2-3 / 4$ the length of the receptacle 58

b. Basal bracts usually $4-10 \mathrm{~cm}$ long, covering up $1 / 3(-1 / 2)$ the length of the

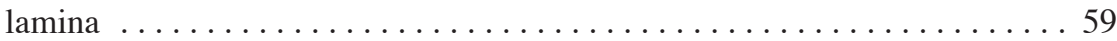

58a. Apex of lamina acuminate, the acumen acute; basal bracts broadest below the middle, the apex often obtuse. - Java . . . . . . . . 36. F. involucrata

b. Apex of lamina short-acuminate, the acumen obtuse; basal bracts broadest above the middle, the apex rounded. - Sulawesi, Moluccas, New Guinea . . . . . . . . .

26a. F. crassiramea subsp. crassiramea

59a. Midrib (and lateral veins) \pm impressed above; stipules brownish to whitish sericeous to puberulous; base of lamina mostly (sub)cordate with a narrow sinus. - Malay

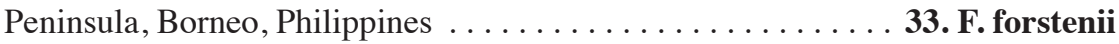

b. Midrib (and lateral veins) slightly prominent to flat or the midrib sometimes slightly impressed; stipules glabrous or white (minutely) puberulous; base of lamina mostly cuneate to rounded $\ldots \ldots \ldots \ldots \ldots \ldots \ldots \ldots \ldots \ldots \ldots \ldots \ldots \ldots$

60a. Apex of lamina acuminate, the acumen acute; basal bracts broadest below the middle, the apex often obtuse; areoles of lamina obscure beneath. - Wide-

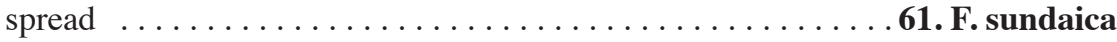

b. Apex of lamina short-acuminate, the acumen obtuse; basal bracts broadest above the middle, the apex rounded; areoles of lamina usually distinct beneath because of prominent veinlets. - Sulawesi, Moluccas, New Guinea

$\ldots \ldots \ldots \ldots \ldots \ldots \ldots \ldots$. . . F. crassiramea subsp. crassiramea

61a. Ostiole closed, the 3 upper ostiolar bracts clearly imbricate $\ldots \ldots \ldots \ldots 62$

b. Ostiole \pm open, the 3 upper ostiolar bracts not or partly imbricate . . . . . 63 
62a. Basal bracts semicircular to suborbicular, imbricate, the apex rounded; areoles of lamina usually distinct beneath because of prominent veinlets. - Eastern Malesia .............. 26a. F. crassiramea subsp. crassiramea

b. Basal bracts ovate, not (or only basally) imbricate, the apex obtuse; areoles of lamina obscure beneath. - Widespread ...........61. F. sundaica

63a. Basal lateral veins branched; lateral veins (3-)4-6 pairs. - Sumatra, Malay Peninsula, Java, Borneo, Philippines . . . . . . . . . 51. F. pisocarpa

b. Basal lateral veins (usually) unbranched; lateral veins 6-12 pairs . . . . . . 64

64a. Basal lateral veins $1 / 4-1 / 3(-1 / 2)$ the length of the lamina; apex of lamina rounded to short-acuminate, the acumen obtuse; leafy twigs, petioles, and stipules usually

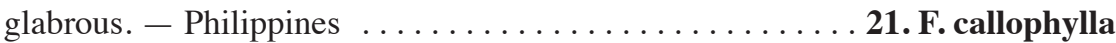

b. Basal lateral veins up to 1/10-1/4 the length of the lamina; apex of lamina acuminate, or if short-acuminate to rounded, then the leafy twigs, petioles, and stipules

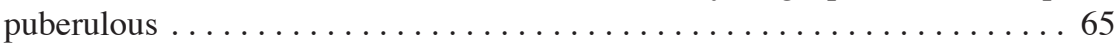

65a. Fig receptacle ellipsoid. - Sumatra, Malay Peninsula, Borneo, Philippines ...

50. F. pellucidopunctata

b. Fig receptacle ovoid. - Sumatra, Borneo . . . . . . 10. F. acamptophylla

66a. Fig receptacle $1-2 \mathrm{~cm}$ diam. when dry . . . . . . . . . . . . . 67

b. Fig receptacle $0.3-1 \mathrm{~cm}$ diam. when dry $\ldots \ldots \ldots \ldots \ldots \ldots \ldots$

67a. Indumentum on various parts (as leafy twigs and midrib of the lamina beneath)

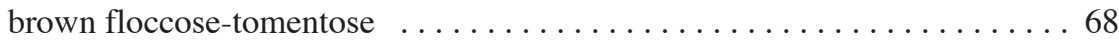

b. Indumentum not floccose-tomentose . . . . . . . . . . . . . . . . 69

68a. Apex of the fig receptacle concave, the ostiole sunken; stipules $2-6 \mathrm{~cm}$ long, subpersistent. - Sumatra, Malay Peninsula . . . . . . . . 19. F. bracteata

b. Apex of the fig receptacle convex to submammillate, the ostiole \pm prominent; stipules 1-2 cm long, mostly caducous. - Sumatra, Malay Peninsula, Java,

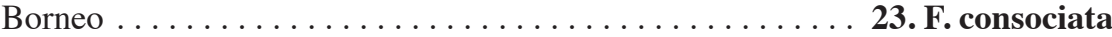

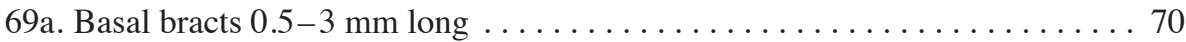

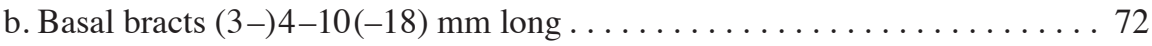

70a. Midrib impressed above; areoles of the lamina conspicuous beneath. - Malay

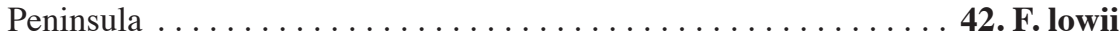

b. Midrib slightly prominent to flat (or slightly impressed towards the base); areoles

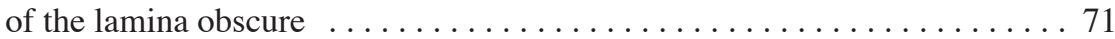

71a. Apex of lamina acuminate; petiole $2-5 \mathrm{~cm}$ long. - Borneo . . . 25. F. corneri

b. Apex of lamina rounded (to obtuse); petiole (0.5-)1-2(-3) cm long. - Sumatra?, Malay Peninsula ................. 28. F. curtipes

72a. Lamina on the midrib above and the midrib and lateral veins beneath white puberulous; base of the lamina cordate to rounded. - Cultivated . . . . . . . .

15. F. benghalensis

b. Lamina above and beneath glabrous or sometimes minutely puberulous on the midrib beneath; base of the lamina cuneate to rounded $\ldots \ldots \ldots \ldots \ldots 73$

73a. Midrib (at least the lower part) impressed above; base of lamina cordate to rounded. - Borneo .................. 48. F. paracamptophylla

b. Midrib of lamina slightly prominent to flat; base of lamina usually cuneate to rounded 
74a. Basal bracts semicircular to suborbicular with a rounded apex, imbricate, covering $1 / 3-2 / 3$ of the receptacle. - Widespread

26a. F. crassiramea subsp. crassiramea

b. Basal bracts (broadly) ovate, not (or only basally) imbricate with an obtuse to acute or to rounded apex, covering up to $1 / 3$ (or 1/2) of the receptacle . . . 75

75a. Apex of the lamina acuminate, usually with an acute acumen; basal bracts ovate, not or only imbricate at the base. - Widespread ........66. F. sundaica

b. Apex of the lamina rounded to obtuse, or if acuminate, then with an obtuse acumen; basal bracts semicircular to broadly ovate, \pm imbricate . . . . . . 76

76a. Base of the lamina and the lower part of the margin not (or hardly) callose; smaller veins of the lamina, even the reticulum \pm clearly visible beneath; basal bracts usually covering $1 / 2$ or more of the fig receptacle. - Widespread

26a. F. crassiramea subsp. crassiramea

b. Base of the lamina and (at least) the lower part of the margin \pm distinctly callose; smaller veins of the lamina usually not clearly visible to obscure; basal bracts

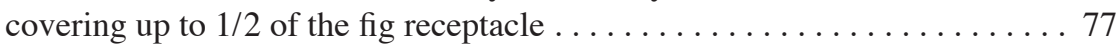

77a. Lateral veins 6-10 pairs; apex of the lamina (usually) short-acuminate. - Widespread

21. F. callophylla

b. Lateral veins 10-13 pairs; apex of the lamina (usually) rounded. - Sumatra?,

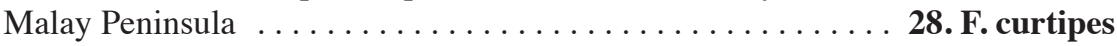

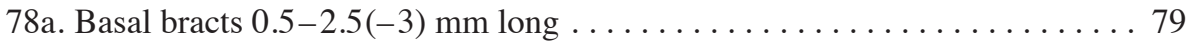

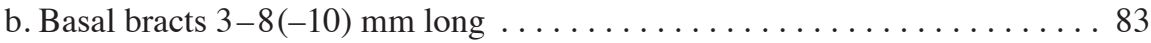

79a. Ostiole open, the 3 upper ostiolar bracts not or slightly imbricate $\ldots \ldots \ldots 80$

b. Ostiole closed, the 3 upper ostiolar bracts clearly imbricate . . . . . . . . . 82

80 a. Lamina \pm densely puberulous on the veins beneath. - Malay Peninsula . . . . .

52. F. pubilimba

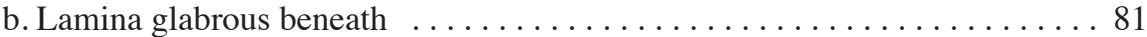

81a. Stipules glabrous. - Sumatra, Malay Peninsula, Java, Borneo . . . . . . . . . .

17. F. binnendijkii

b. Stipules yellowish sericeous. - Malay Peninsula . . . . . 43. F. maclellandii

82a. Basal lateral veins up to $1 / 20-1 / 10$ the length of the lamina; apex of the lamina short-acuminate. - Sumatra, Malay Peninsula, Java, Borneo, Philippines . . . . .

38. F. kerkhovenii

b. Basal lateral veins up to usually $1 / 4-1 / 3$ the length of the lamina; apex of the lamina usually rounded. - Sumatra?, Malay Peninsula . . . . 28. F. curtipes

83a. Indumentum on various parts (as stipules and midrib of the lamina beneath) brown floccose-tomentose. - Sumatra, Malay Peninsula, Java, Borneo

23. F. consociata

b. Indumentum not floccose-tomentose $\ldots \ldots \ldots \ldots \ldots \ldots \ldots \ldots \ldots \ldots$

84a. Leafy twigs (and often also on other parts) with abundant small dark brown appressed hairs; tertiary venation \pm prominent beneath $\ldots \ldots \ldots \ldots \ldots$

b. Leafy twigs without such hairs or if present, then very sparse and inconspicuous; tertiary venation (almost) flat beneath $\ldots \ldots \ldots \ldots \ldots \ldots \ldots \ldots \ldots \ldots$

85a. Petiole $0.5-1 \mathrm{~cm}$ long; apex of the lamina rounded; tertiary venation of the lamina slightly prominent (rather inconspicuous). - Java, Borneo (southern) . . . . . . . 
b. Petiole (0.5-)1-2.5 cm long; apex of the lamina acuminate to rounded; tertiary venation prominent (and conspicuous). - Sumatra, Malay Peninsula, Borneo .

39. F. kochummeniana

86a. Ostiole \pm open, the upper 3 ostiolar bracts not or partly imbricate . . . . . 87

b. Ostiole closed, the 3 upper ostiolar bracts clearly imbricate . . . . . . . . 90

87 a. Basal lateral veins up to $1 / 10-1 / 4$ the length of the lamina . . . . . . . . 88

b. Basal lateral veins up to $1 / 4-1 / 2$ the length of the lamina . . . . . . . . . . 89

88a. Fig receptacle $0.3-0.6 \mathrm{~cm}$ diam. when dry; basal bracts $1-2 \mathrm{~mm}$ long. - Sumatra,

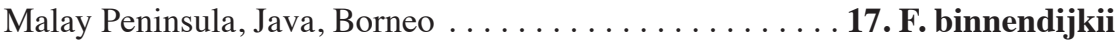

b. Fig receptacle (0.5-)0.7-1.2 $\mathrm{cm}$ diam. when dry; basal bracts $3-5 \mathrm{~mm}$ long. -

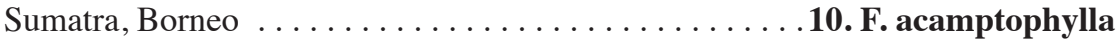

89a. Lateral veins $6-10$ pairs, the basal pair unbranched, sometimes faintly branched. - Widespread ..................... 21. F. callophylla

b. Lateral veins (3-)4-6 pairs, the basal pair branched. - Widespread ........

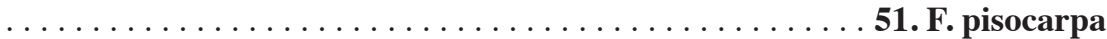

90a. Lateral veins 10-13 pairs. - Sumatra?, Malay Peninsula . . . 28. F. curtipes

b. Lateral veins $(3-) 4-8(-9)$ pairs . . . . . . . . . . . . . . . 91

91a. Basal bracts 3-5 mm long; apex of the lamina rounded. - Java, Borneo (southern) . . . . . . . retusa

b. Basal bracts $5-8 \mathrm{~mm}$ long; apex of the lamina acuminate . . . . . . . 92

92a. Base of lamina auriculate to cordulate; fig receptacle depressed-globose. -

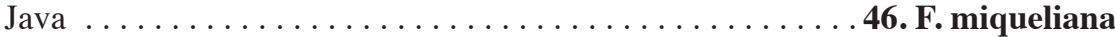

b. Base of lamina cuneate to rounded; fig receptacle subglobose to ovoid to ellipsoid

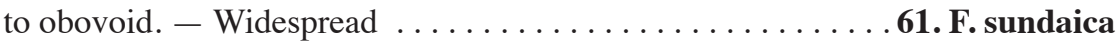

\section{KEY TO THE SPECIES OF SECTION STILPNOPHYLLUM}

1a. Aperture of the ostiole circular; stipules connate . . . . . . . 64. F. elastica

b. Aperture of the ostiole slit-shaped or tri-radiate; stipules free $\ldots \ldots \ldots \ldots .2$

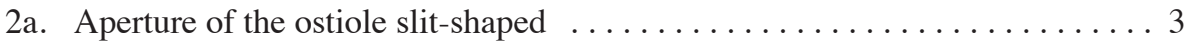

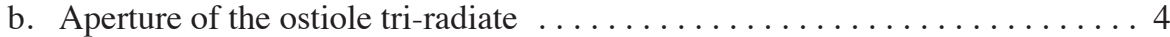

3a. Lateral veins 9-14 pairs; apex of the peduncle \pm dilated; fig receptacle $0.4-1 \mathrm{~cm}$ diam. when $\operatorname{dry} \ldots \ldots \ldots \ldots \ldots \ldots \ldots \ldots \ldots \ldots \ldots . \ldots \ldots$. F. rhizophoriphylla

b. Lateral veins (12-)15-25(-30) pairs; apex of the peduncle extended into a cu-

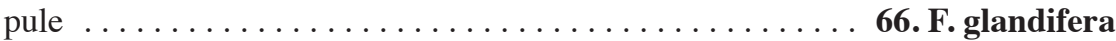

4a. Stipules 4-20 cm long; fig receptacle 1-4 cm diam. when dry, mostly ellipsoid 67. F. hesperidiiformis

b. Stipules 1-3 cm long; fig receptacle $0.3-1.2 \mathrm{~cm}$ diam. when dry, subglobose 5

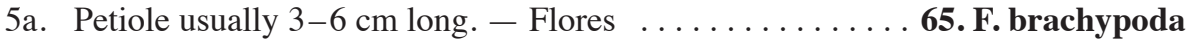

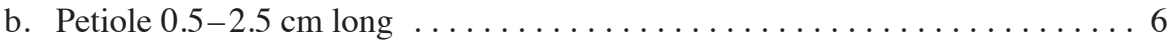

6a. Periderm of the twigs flaking off; lamina mostly broadest below the middle. Lesser Sunda Islands

65. F. brachypoda

b. Periderm of the twigs persistent; lamina broadest in the middle. - Moluccas, New Guinea

68. F. obliqua 


\section{ACKNOWLEDGEMENTS}

The Flora Malesiana Foundation supports the preparation of the treatment of Moraceae for Flora Malesiana. Dr. J.F. Veldkamp (Leiden) translated the diagnoses into Latin. The help to obtain data of collections needed for the preparation of the series of precursors for the Ficus treatment in Flora Malesiana given by Dr. D. Dixon (Palmerston), Dr. Iriwati (Bogor), Dr. R. Kaipranis (Lae), Dr. R. Kiew (Singapore), Dr. D.A. Madulid (Manila), Ms V. Noble (London), Dr. Abang Mohtar Abang Pawozan (Kuching), Dr. J.T. Pereira (Sandakan), Dr. M. Sinjappa (Howrah), Dr. U. Starck (Berlin), Dr. J.B. Sugau (Sandakan), Ms M. Thomas (Kew), and Dr. E. Wood (Cambridge), is gratefully acknowledged.

\section{REFERENCES}

Berg, C.C. 2002. Ficus baola, a new species of Ficus subgenus Urostigma section Malvanthera (Moraceae) from the Solomon Islands. Blumea 47: 316-317.

Berg, C.C. 2003. Flora Malesiana precursor for the treatment of Moraceae 1: The main subdivision of Ficus: the subgenera. Blumea 48: 167-178.

Berg, C.C. \& J.T. Wiebes 1992. African fig trees and fig wasps. Verh. Kon. Ned. Akad. Wet., afd. Natk., 2de reeks, 89: 1-298.

Corner, E.J.H. 1958. An introduction to the distribution of Ficus. Reinwardtia 4, 3: 15-45.

Corner, E.J.H. 1960. Taxonomic notes on Ficus Linn., Asia and Australasia. I. Subg. Urostigma (Gasp.) Miq. Gard. Bull. Singapore 17: 368-404.

Corner, E.J.H. 1961. Taxonomic notes on Ficus Linn., Asia and Australasia. Addendum. Gard. Bull. Singapore 18: 83-97.

Corner, E.J.H. 1965. Check-list of Ficus in Asia and Australasia with keys to identification. Gard. Bull. Singapore 21: 1-186.

Dixon, D.J. 2001a. Figs, wasps and species concepts: a re-evaluation of the infraspecific taxa of Ficus macrophylla (Moraceae: Urostigma sect. Malvanthera). Austral. Syst. Bot. 14: 125-132.

Dixon, D.J. 2001b. A chequered history: the taxonomy of Ficus platypoda and F. leucotricha (Moraceae: Urostigma sect. Malvanthera) unravelled. Austral. Syst. Bot. 14: 535-563.

Dixon, D.J., B.R. Jackes \& L.M. Bielig. 2001 . Figuring out the figs; the Ficus obliqua- Ficus rubiginosa complex (Moraceae: Urostigma sect. Malvanthera). Austral. Syst. Bot. 14: 133-154.

Endlicher, S.L. 1848. Genera Plantarum. Suppl. 4, 2: 1-95. Vienna.

Gasparrini, G. 1844. Nova genera, quae supper nonnullis Fici specibus struebat. Napoli.

Kochummen, K.M. 1998. New species and varieties of Moraceae from Malaysia. Gard. Bull. Singapore 50: 197-219.

Laman, T.G. \& G.D. Weiblen. 1998. Figs of Gunung Palung National Park (West Kalimantan, Indonesia). Trop. Biodiversity 5: 245-297.

Miquel, F.A.W. 1847. Prodromus monographiae Ficuum. London J. Bot. 6: 514-588.

Miquel, F.A.W. 1859. Flora Indiae Batavae 1, 2. Amsterdam.

Miquel, F.A.W. 1867. Annotationes de Ficus speciebus. Ann. Mus. Bot. Lugd.-Bat. 3: 260-315.

Schumann, K. \& K. Lauterbach 1905. Nachträge zur Flora der deutschen Schutzgebiete in der Südsee. Leipzig. 